\title{
Corporate Social Responsibility, Brand equity, and Shareholder Value: Theoretical and Conceptual Perspectives.
}

\author{
Asim Ali Chaudhry, Suresh A/L Ramakrishnan
}

\begin{abstract}
From the last many years, researchers, administrators, and educators consistently paying attention to corporate social responsibility. However, no study analyses the association between corporate social responsibility, brand equity, and shareholder value. The objective of this research paper is to produce a review as to the strength to which corporate social responsibility and brand equity are predictor variables for shareholder value, with the ground that organizations must be wilfully positioned for them to tackle the anticipation convenient in their environments. In connection to this study, the shareholder, stakeholder, and resource base view theories form the base for the underpinning theories used for drawing up the research framework with respect to the connection among shareholder value, corporate social responsibility and brand equity simultaneously. Very few research attempts are made in this area of study in the emerging and developed nations, especially with shareholder value and brand equity. Therefore, practitioners and scholars are inspired to progress in the development of the body of knowledge in this research field for the universal enrichment of output, as the review form a concept of corporate social responsibility and brand equity as a critical tool for boosting shareholder value locally and internationally.
\end{abstract}

Index Terms: Corporate Social Responsibility; Brand Equity; Shareholder Value.

\section{INTRODUCTION}

In common it is assumed that a firm should be liable for all the conduct they do, socially and ethically. It is important to determine the effect of the company on the social welfare and environment. The definition of corporate social responsibility could be as, the awareness of the organization approaching the general public and social environment. It advises us to know what firm is accomplishing with their profits and how they are moving towards society. As with the flourishing determinants in the economy and promotion in business strategies the companies are not only answerable to shareholder but also to the stakeholders such as community, employees, supplier, and consumer.

It is fundamentally a partnership between socially active groups and business corporations for the objective of community growth and social development. In the actual

Revised Manuscript Received on September 22, 2019

Asim Ali Chaudhry, Faculty of Azman Hashim International Business School (AHIBS), Universiti Teknologi Malaysia (UTM), 81310 Johor Bahru, Johor, Malaysia, asimalich@yahoo.com

Suresh A/L Ramakrishnan, Faculty of Azman Hashim International Business School (AHIBS), Universiti Teknologi Malaysia (UTM), 81310 Johor Bahru, Johor, Malaysia. view, corporate social responsibility is the affiliation of business operations with social standards. Corporate social responsibility is said to be the vital component of the business organizations that not only contribute to outclass the business competitors but also support to evolve the business in society.

The financial wrongdoings, for example, WorldCom, Enron, Paramalat, etc universally have compelled the firm's executives to give more consideration to an extensive strategy that further attract the view of shareholders value enhancing. A common belief is that the prestige of the organization and the welfare of different stakeholders are vital to shareholders value as well as for gaining long-run continuity of the organization. We postulate that investors do trail these socially responsible firms and their indicators and any massive fluctuation in the index are shown in the extraordinary returns of these companies in the capital market.

Organizations must execute well and become aware of CSR projects that assist allocating the political, economic and social advantages to the groups from which they acquire their potential [1]. [2] justify this model, that shareholder's attractions sometimes conflicting with socially responsible practices, their announcements and accordingly with other stakeholders' concerns [3]. Mostly shareholders aim the long-run continuity of the organization and sustaining their own honor which means enhancing the company economic environmental and social behavior and a suitable communication of firm's behavior to the market to boost their fame. [4]. The institutional investors also involve in the CSR resolutions applying the method of corporate governance [5] .

CSR has now developed into a firm's compulsory Versus an elective exercise. According to [] ] examining global brands realizes, that 90 percent of Fortune 500 firms take part in the activity of CSR actions [6],[7]. Corporate social responsibility is exceptionally essential for big brands because it symbolizes origin of competitive advantage [7]. Further, big firms are greater apparent to customers and accordingly greater exposed to critiques for deficient business methods. Therefore, in these scenarios, Corporate social responsibility can influence unfavourable consequences for companies.

For instance, the CSR activities of brands usually 
assumed as they are working for themselves or in their interests, which can minimize their impacts on brand equity []].

Customers grow into familiar with ethical consumerism during social movements; most have no longer friendly response to firms that only making extra profits. Instead, consumers have started to predict organizations to behave as better nationals and not only build returns [9]. CSR is often observed as a redundant load because it is expensive but does not generate a momentous return; therefore, it has the long-run monetary benefit [10] . Brand equity stated as a vital essential to make the value of a brand and increasing an organization's competitive edge in the market [10]. Significantly, Corporate social responsibility is a direction to boost brand equity and to advance a firm's definite representation while drawing the attention to potential and current consumers [11].

Many types of research have examined that CSR activities are valuable for firms because they contribute diverse and fascinating advantages in different forms like, developing corporate image and enhancing brand awareness [12-14]. In [15] state that consumers have a positive opinion to firms who have a favorable corporate reputation. CSR activities by firms will make a healthy corporate image called intangible assets, such as brand equity [16], [17] . Corporate social responsibility is, however, indicating to as "Social Marketing" because it could establish brand equity [18] .

Theory of classical conditioning [19] in which human beings determine about a stimulus that is a brand by relating it with another object. When the cause of firms become to do more and more CSR activities, then these cause of CSR activities associated with the brand, by this customers view the brand as more socially responsible [18],[20]. Brand differentiation perceived by the customer for the purpose to categorize the product or a service in order to form a brand equity although brand differentiation is determined through the value of components that brand offers [21].

In the signaling theory perspective, people are willing to utilize their understanding and observation to know about company prestige as a signal because mostly not having the talent to know about the well-being of company [22],[23]. Companies that are involved in CSR activities, it is their attribute that satisfies and attract their stakeholders as a signal.

[24] examined that customers enthusiasm to purchase or advise a product is compelled 60 percent by the impressions of the firm and only 40 percent by the impression of the product. Notably, the research also shows that 42 percent of how the general public sense of a firm is borrowed from their understanding of the firms CSR activities. If this, what method determine the connection between customers CSR perception and Corporate image? Inside the literature of academic, less is familiar around the method of CSR activities impact brand equity and corporate reputation, even then it is broadly known that CSR effects brand equity and corporate image[25],[21] .

Brand valuation catches the photograph of a current value of expected forthcoming cash flows, to arise from a company brand investment. Organizations construct profitable brands through their new product development attempt, Research, and Development, communications campaigns, also by the additional essential features of marketing mix. The eventual objective of such financings is to boost investor value by enhancing brand equity in the view of their consumers [26]. Researches made in the past evaluating the connection between shareholder value and brand value have been thriving all along the previous 15 years [27],[28]. These researches indicate that firms acknowledge profitable brands as an intangible asset that develop immense benefits, containing encouraging repeat purchasing, build greater consumer faith, admit exceptional prices and low price flexibility, allowing fresh product launching, building a low fence to competitive market access and acquiring an extra decent origin of forthcoming cash flows [29, 30]. Unsurprisingly, [31] establish that a brand with high value experiences a "higher turnover, profit, and surplus consumer utility". Some researchers implicitly receive the connection of brand value to shareholder's wealth [32].

Investors are to a higher intensity leading their consideration that how stocks behave in the stock exchange, which has exercised an extreme strain on firms to transfer profits [33-35] . However, the subdivision of marketing should also evolve into the duty for achieving short-run profit objectives [36] has enter to look at the eventual objective as providing maximum value to shareholders [37-41]. In addition, the departments of finance and marketing in a firm will perform consistently to gain the essential objective of enhancing the wealth of shareholder [42],[39]. Simultaneously, a valuable modification should be given to the economy, indicated with a higher extent of significance could be delivered to intangible assets as compared to conventional physical assets. [43],[44] it is ordinary in these days to explore firms with greater value in the means of intangible assets as compared to tangible products. Therefore, intangible assets are normally not subsidized by such different financing on balance sheet [43].

The brand is stated as an illustration of an underestimate asset, likely in balance sheet it is not included [36]. In most scenarios, intangible assets said to be important for producing compelling shareholder value and business progress. [36, 44, 45] brand equity has been acknowledged as a vital crucial asset for a firm [46],[47]. Unluckily, few firms may be restrained to obtain the brand as an asset, because they are lacking in their marketing competence in the way of culture, processes, and people [48]. However, many researchers recognize brands as firms most priceless asset [49-52]. Aaker [48] call for attention that brands "serve as the core of a customer relationship, a platform for strategic options, and a force that affects financials, including stock return". Brand equity stated as an essential component in the approach and process of marketing [53], establishing its part in boosting the wealth of shareholder featuring the significance and consideration that the firms and those accountable for the field of finance and marketing 
will provide to brand equity, to enhance wealth for the investors.

[36] refer to that there exist a "belief that strong brands result in better earnings and profit performance for firms, which in turn, creates greater value for shareholders" and this is parallel in line with findings of [54], convey advice that particular shareholders have a tendency to financing in firms with surely appreciable products, also by [48] that admits powerful brands as " the basis of competitive advantage and long-term profitability going forward". Even though there exist a flourishing acceptance of brand equity value, it is compulsory to accumulate more experimental confirmation revealing brand equity to the creation of wealth to shareholders [27],[2] ].

\section{CONCEPTUAL FRAMEWORK BASED ON THEORATICAL FOUNDATION.}

Stakeholder theory stated that an organization will accommodate their distinct stakeholders, stakeholders are stated as individuals or groups who are overwhelmed by the accomplishment of the organization's goal [55]. According to this approach, organization requirement to acknowledge how their responses affect stakeholders such as employees, suppliers, consumers, etc [56-58]. When the organization contributes to the requirement for its stakeholders, this will assure that the organization can persist to perform. CSR is qualified with stakeholder theory because it can be observed as a connection between stakeholders and the organization [59-61]. A pleasant connection with stakeholders can sustains if organization stick to their promise regarding society [62].

Organizations have a liability to the community. Few academics have a dispute that is not matched with the principal goal of an organization, which is known as enhancing wealth for shareholders. There are also a group of researchers considers that the expense of CSR is more than the advantage it can constitute [63],[64]. Few scholars realize that CSR activities derived from the encouragement that managers need to be view as an answerable administrator and this happens at the shareholders cost [드]. Shareholder approach possess that the single goal of an organization is to increase shareholders wealth. By having honest with the capital of the shareholders, is appropriate for the shareholders wealth [66].

The theory that provides a base to the connection among CSR and Brand Equity is the resource-based view theory [67]. Resource based view theory supports that a firm comprises two types of resources one is tangible resources and the other is intangible resources [68]. Continuous competitive advantage could be attained when the resources are contrary and stagnant. CSR can enhance positive image and boosts brand loyalty and images, which are features of Brand Equity. These intangible resources can create a continuous competitive advantage for a company and difficult to mimic [69]. However, the CSR and Brand Equity relationship shares vital return to a company.

This concept is persistent with the resource-based theory (RBT), that postulate a structure regarding the market-based capabilities and assets are leveraged to maintain and attain the admirable shareholder returns and corporate performance [70].Established on this proponents RBT [71],[72] admit that a firm can gain and attain competitive advantage through marketing-specific resources that is brand and customers. They also draw the attention that in times of instability, change and volatility brands and brand-building engagements serves the protection to a firm [47].

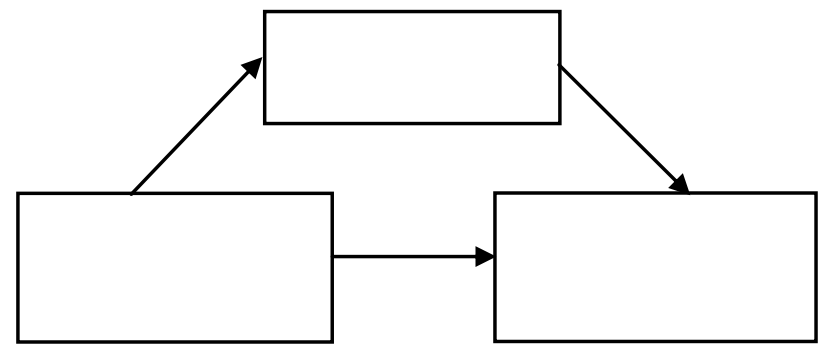

\section{A. Corporate Social Responsibility.}

Corporate social responsibility can be viewed in different prospects but many of the definitions are describing the firm that enforces a program or form of doing business that influences the peoples out of the firm in a conclusive way. $[73,74]$ gives the definition of Corporate Social Responsibility as "A strategic decision whereby an organization undertakes an obligation to society, for example in the form of sponsorship, commitment to local communities, attention to environmental issues, and responsible advertising" (p. 1). There are different school of thoughts that take a view what the Corporate Social Responsibility is and should be, but one thing is common in that is they have a responsibility towards society as they are operating a business in the society. Two schools of thoughts are famous one is matured by [74],[75].

[76] states that the primary responsibility of any firm is to maximize the profits to its shareholders, stakeholders, and society. He takes the concept of free market capitalism that any humanitarian operations should be done by persons and not by firms on behalf of the persons. He further states that when the company maximizes their profits, through profits living standards of employees can improve, provides better returns to shareholders and improves the overall sustainability of the company. More importantly, Friedman states that any action does not lead to maximizing profits criteria should not be employed in the company.

In divergence to Friedman, [77] matured the concept that the primary responsibility of businesses towards society consists of four dimensions. Carroll forwarded the concept that the responsibility of a business is to employ a philanthropic activity and employ an ethical practice that may go after basic legal essentials. He further argues that businesses do not only develop to fulfill the economic and legal demands and assumptions of the greater society and shareholders.

Carroll view that businesses identified the responsibility of not only penetrate in honor shareholder's investment but

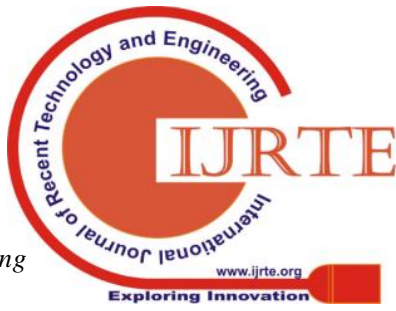


also identified the business to go beyond society than just economies. Carroll approach is that institutions are the members of the society rather than institutions of the society.

\section{B. Shareholder Value.}

In a contemporary economy, the entrepreneur firm has been one of the major monetary institutions, it has a massive significance when we speculate its performance. The determinants in the analysis of firm performance are of ultimate importance to all stakeholders of a company, specifically to common equity venture capitalists.

Value theory states that the main goal of the firm is maximizing profits and broadly the present value of the firm. In traditional theory perspective, those firms which are not able to maximize the returns are replaced by others or disappears and only firms which can maximize returns only survive [78]. In the 1890s the glorious economist Alfred Marshall was one of the first economists who spoke about the concept of monetary profit, that a firm can earn if it covers all costs including operating cost and invested capital cost [79] .

This approach is different from the classical approach in which measurement of accounting profits and related ratios are borrowed from Return on Equity (ROE) and the Return on Assets (ROA). Through this new approach that is Shareholder Value Creation (SVC) new measures of performance has been achieved [79]. The difference in classical and new approach is that the performance measurement yardstick is different, in classical approach the cost of invested capital (equity and debt) does not include to setup profits by a company. In classical approach if the comparison of two companies are made on the bases of ROE(Return on Equity) then two companies that contains equal ROE considers equally successful, however in the new approach that is shareholder value creation approach same results are not compatible with these two firms that are different in terms of cost of capital, or we can say that in other terms if there is a difference in residual income or economic profit [79]. Rappaport has also thrown light on the approach of Shareholder Value in 1986 in the book written by him named Creating Shareholder Value. In his book, he expresses a clear emphasis on shareholders' value [이].

The financial professionals on the present day have making underline the concept of wealth maximization of principle or owner of the companies that are Shareholders. The measure that is related to Shareholder value creation is maximizing wealth. The meaning of the Shareholder Value Creation is to produce profits for the absolute holders of the company that is the Shareholders. In other words, we conclude that returns exceed from the cost of capital is treated as Shareholder Value. Consequently, there are categories of companies, some are profit makers (profits higher than the cost capital) and some can be profit destroyer (profit lower than the cost of capital).

\section{Brand Equity.}

Aimed intense competition, brand value can add tremendous profits in businesses that is why brand value has grown into a fundamental topic in corporations. One can boost long-term profitability by adding brand value in the corporation [50]. Brand Value has been often used reciprocally [1-83], Brand Equity definition given by [50] is " a set of brand assets and liabilities linked to a brand, its name and symbol, that adds to or subtracts from the value provided by a product or service to a firm and/or to the firm's customers". The definition shows that brand equity is an asset infect profitable asset that enhances firm wealth.

Researchers have researched on three prospects of brand equity the financial view [84], the product view [ $\underline{85}$ ] and the customer-based view[50],[83]. Each prospect has its pros and cons, of course. Brand equity, product view spotlight on the activities of the market going on and the financial view emphasis on the objectives and subjective segments measures to calculate brand equity in the future. By comparison, the customer-based view figures out that to how much extent customers are familiar with the brand, to what degree customers are knowledgeable about the brand and what preference customer give to a brand specifically [86].

A brand has been perceived as a significant part of the corporate policy, through brand a firm can obtain long-run profitability and financial outputs [87]. The brand is used to differentiate the goods, services, and companies from competitors. A brand can be design, term, symbol, name and could be a combo of them. Through brand, a firm can obtain a competitive advantage because the brand is a profitable, unique and intangible source of wealth.

With strong brands, global standing of the firm enhances, and corporate status also established [88]. A dynamic brand structure features a strategic objective, particularly in the international market. Globally a powerful brand increases the probability of purchases [89]. Powerful brands can boost by exercises that show it, and other partnerships that make the firms or product noticeable and therefore visible. Researchers in many types of research analyses the term brand equity and there are many prospects in examining the term that what does it mean [90]. Though, defined generally by the brand name as its value indulges to a product.

Brand equity can be calculated by two ways either consumer related or financially. Through financial measure, it is calculated either by replacement cost or by stock price. To seizure, the effective essence of brand equity [91] adopt movement price, according to the theory that future anticipations of stock market prices reflect brand position. In acquiring firm, brand equity is used as a valuable indicator [92]. Further, [91] introduced another tool is used when the company launches a fresh brand. The base of this tool is a brand replacement, or the demand of capital to build a fresh brand, synchronously with the expectation of favourable outcome. The best recognized financial tool which is adopted by Financial World in its annual listings for valuation of the brand of world brands [93].

Financial World calculates brand-related profits by using a formula and then assign a multiple based brand strength.

Brand in extension to highlighting the offers of the 
company could facilitate what customer demands, reduce risk, promise, quality and build confidence by following the experience of the customer by the product they refer [94]. Brands are treated strong because of their performance in the market and brands are providing values to its customers and company that is why the brand is considered important asset [48],[95] . As an intangible feature, sellers make a promise with its customers and guarantee them that he will frequently distribute products related with a brand in a good quality level that will benefit the customer and for its convenience [47].By studying the concept of branding, the practices of marketing established brand equity as an asset that creates wealth for the organization [96].

The "firm/company-based brand equity perspective", is defined as "the intangible wealth emanated from the incremental capitalized earnings and cash flow achieved by linking a successful, established brand name to a product or service" [97]. It considers both views the product view and financial market view on a brand, the brand has a capability of attracting revenues, returns, cash flow and profits to a company. The firm-based brand equity has a macro focus, it not only explains the relationship between customer and brand but also describes the benefits of brand equity that a company can get. [94].

Brand equity is stated as by adding the value of a brand to a product [90]. In the present scenario, peoples are so much busy in their work and life, so they have less time to purchase the products but lots of products available in the market, so brand equity plays a vital role in purchasing the product. Those products which have higher brand equity consumers preference those brands to purchase. So, brand equity plays a crucial role in purchasing among choices and helps customers in their decision-making regarding product purchase and customers satisfaction [90].

\section{DEVELOPMENT OF HYPOTHESIS IN RELATION TO THE CONCEPTUAL FRAMEWORK.}

\section{A. Corporate Social Responsibility \& Shareholder Value.}

There are different views of corporate social responsibility. From the review of CSR literature, two principle perspectives and results show that investors and stockholders do not concentrate much on CSR [98]. [99] propose that from the stakeholder viewpoint CSR has a positive effect on firms' financial performance. Because the organization has the connection with different stakeholders such as consumers, government, environmental advocates and competitors, enhancing the social contribution can turn into good stakeholder connection, which results minimize the social cost and boosts market favorable circumstances, directing to maximum financial performance. [100] show that organizations with a maximum CSR rating normally supply maximum returns than those with low Corporate social responsibility ratings. [101] show that contributing money to the best firm's citizens, the outcome in greater market performance.

[102], [103] find that CSR activities positively impact a firm's financial performance because CSR engagements can solve issues between stakeholders and managers.[104] examined the impact of CSR on company performance. The findings reveal that CSR has a positive connection with ROCE and MBV because when firms are engaged in focusing more and more doing CSR engagements ultimately, they get a competitive advantage on others. [105] by checking the relationship between CSR reporting and economic performance in Bangladesh listed firms. The results of the study reveal that CSR reporting increases firm performance under market and accounting performance measures. Because due to unrestricted CSR reporting by organizations in Bangladesh increase value of the organizations and the relationship between shareholders and stakeholders is enhanced. As a result, this payback to shareholders in a positive way. [106] examined the impact of CSR on Firm's financial performance. He calculates ROA, ROE, EPS for financial performance in Pakistan Banking Industry. By applying the pooled regression model, he finds that CSR has a significant and positive effect on ROA, ROE, and EPS. Because commercial banks in Pakistan investing money on CSR activities that is why these CSR activities positively affect their financial performance. [107] by analyzing that CSR activities can influence shareholders value in India. Results show that only power and infrastructure has a significant impact on the shareholders' value, while other sectors did not have any significant relationship. The researcher argues that these four sectors should pay immediate attention to CSR activities before making an investment decision in these sectors. The sectors where positive results are obtained investors are paying attention to those sectors on CSR spending and CSR spending's also paying back to Shareholders in a positive way. Considering the preceding, the hypothesis is

H1: CSR has a positive relationship with Shareholder value of companies.

\section{B. Corporate Social Responsibility \& Brand Equity}

The word 'brand' is just not a name or symbol [108] it could create a value that is called as Brand Equity in business literature [50]. [109] describes that if the firm provides its customers with valuable products and services, achieves bigger monetary accomplishments. This approach is indicated as Brand equity [50]. It represents the value combined with the product by the faith of its brand name [110],[90]. In common, it is pretended that brand imitates corporate asset [111]. There are three perspectives of brand equity one is financial, second is a consumer, and third is a company $[\underline{94}, \underline{112}, \underline{113}]$. In recent studies on branding, the focus is on stakeholder co-creation of brand Value [114-119].

[120] examined the connection between CSR, Corporate brand equity, corporate brand credibility, and corporate reputation. The findings show that $\mathrm{CSR}$ and Corporate brand equity has a positive relationship. Also, CSR has a positive relationship among

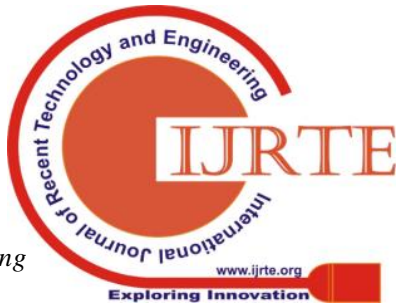


all other variables. The finding extends the area of consumer-brand connection by experimentally display that credibility of the brand increase from the activities of CSR and, in order, evolve into reputational capital in the long run. The finding more indicate that the Researchers of CSR and marketing executive should give the consideration to recognize the cognitive structure of consumer CSR approach.[121] has examined the relationship between changes in CSR perceptions and brand equity by taking marketing capabilities as a moderator. The examiner finds a significant and positive association among CSR perception and brand equity. Moderator also has a significant relation with brand equity and changes in CSR perception. They recommended that CSR perceptions raise (drop) will greatly raise (drop) brand equity. they propose that companies may significantly influence on brand equity via the use of their marketing abilities. This proves shows that a company with powerful marketing capabilities may enhance the advantages of a certain change in the CSR- brand equity connection or check the neutralizing change in CSR perception' $s$ and the impact on brand equity. [122] studied the influence of CSR and Image on Brand Equity. After findings results show that CSR has a positive significant impact on brand Equity and corporate image. Further, brand equity influenced by corporate image. The results indicate that the carryout of CSR edge to the certain mental concept in the minds of customers and the certain mental image will decrease the threat of customer's behaviour and rise in their trust against the brand. According to this, a firm's abilities should be fortified in supporting its image in the customer's mind. In this regard, it can be suggested that the CSR activities are a cause of cut-throat benefits for the firms, after all, it may have effect on consumer's perception of brand equity. [123] examined the CSR effects on Brand Equity of Indian companies. Results show that CSR engagements have a definite effect on Brand Equity. In this research, the result indicates that Corporate Social Responsibility practices are different from other company abilities which directly impact on the performance results of the brand. Company's trustworthy the activities of CSR build the brand perceptibility which draws the attention of promising stakeholders. Although, corporate social responsibility is a company structure which enhances the company's performance in the long term. [124] examined "the influence of customers perceptions of multidimensional corporate social responsibility(philanthropic, ethical, legal and economic) on brand equity". The findings show that in only philanthropic corporate social responsibility had an insignificant effect on consumers perception of brand equity, while other aspects of corporate social responsibility such as ethical, legal and economic have a significant impact on consumers perception of brand equity. According to this, it is important to extend channels to suggest Starbucks' CSR curriculums. The results show that consumer is capable to create brand equity also objectively by assessing a company's legal corporate social responsibility performance; after all, these accountabilities are performed to fixed levels, laws, and regulations. [125] studied the connection between CSR and Brand equity. The authors concluded that governance and diversity-related CSR have a significant impact on Brand equity. The findings show that the connection between the $\mathrm{BE}$ and the elements of CSR are unique over the companies with distinct working manner like as an employee connection and quality of the product. These findings show that correctly amalgamate plan of external CSR and abilities and internal assets will create BE for the company, in the shape of customer-based results, financial-market results, and product-market results Through CSR activities or engagements, brand equity can be increased, because CSR is a vital factor to enhance brand equity of a company. Based on the above, the hypothesis is,

H2: CSR has a positive relationship with Brand Equity of companies.

\section{Brand Equity \& Shareholder Value.}

Typically, Brands are treated with corporate intangible assets. It is usually recommended that they contain economic value and generate profits for shareholders [97, 126, 127]. Therefore, publications that examined the connection among brand equity and shareholder are enormously rare. As mentioned by [97], they stated that build conceptually for the presence of such a relationship needs further attention to justify the compelling links between them. They have concluded that convincing connection between shareholder value and brand equity need still to be settled [97]. Naturally, one could predict that brand equity enhances the market value of the company [127]. Therefore, very less is we with the influence of brand equity imitated in the stock price whether investors in real, value those effects imitated in the stock market. Marketing and finance are two separate pillars in the organization, marketing decisions give less importance as compared to financing decisions of the firm [97]. However, their research agendas are different from each other's, a few researched is done how market react with brand extension policy announcement, product error and customer service changes [128-130]

[111] studied the association between shareholder value and brand equity. It is confirmed that there exists a relationship between shareholder value and brand equity by various indications. Results also reveal that brand performance has a significant impact on firms' value. if the firm's close focus on supervising brand equity and shareholder value they come to know that if the marketing and finance divisions professionals are working closely and cooperatively within an organization, surely, they can increase brand equity and as a result shareholder value also increases. [27] examined the relationship between shareholder value.

Results show that companies that build strong brands eventually create value for the shareholders, and the value is beyond the benchmark and they are creating more value to shareholders with low risk. Means low risk and high returns from investing in valuable brands can get. [131] examined the effect of brand quality on stock returns. Results show that modification in brand

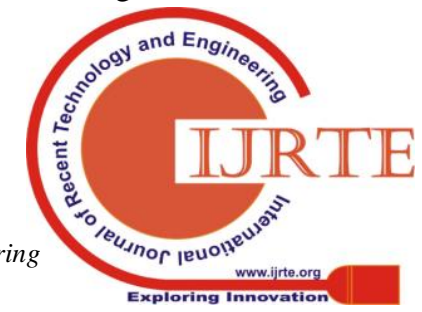


quality boost shareholder value and connected with stock profits and negatively linked with idiosyncratic risk. Still, surprising modifications in the quality of the brand can result in the destruction of shareholder value as they are positively related to systematic risk. [132] studying the impact of the stock market performance of companies that owns high-value brands in good times and bad times. So, the researchers concluded that the period they were observed in their study, an index of the companies that owns the "Best Global Brands" generates abnormal positive profits in the periods of downtrend and uptrend. [133] examined the link among the brand equity and firm risk. In stock returns, firms with higher brand equity face minimum volatility, after controlling firm-specific variables. By boosting brand equity, it becomes a tool for minimising unsystematic risk and downside systematic risk in their stock prices. These results are encouraging for investors and marketing managers, specifically in rising markets where stock prices volatility probably higher relatively in developed markets. [134] make a comparison of stocks between the companies that own higher levels of brand equity with other stock firms listed on the stock exchange of developing countries of Latin America; Peru, Chile, Brazil and Columbia. The findings show that brands with high portfolio represent a lower risk of investment, implying that stocks of companies establish minimum risk investments to shareholders with valuable brands in rising markets. The results of all these findings are significant because the professionals of marketing and finance are working with collaboration. Marketing managers feel justifiable for investments they are making in brands and finance professionals are answerable for shareholders wealth so if they work mutually and with collaboration from brand launching to returns then the results will be positive and significant. A question in the marketing is of a great concern that is the spending of marketing will payback or not in a positive way [42]. Actions of marketing accountable financially is a great concern in marketing practice and theory. According to signalling theory [135] from a marketing point of view that brand equity can be employed to send a signal from companies to customers. Investors want to invest in those firms that have high-value brands because they assume that a firm with high-value brands has good marketing capabilities, managerial professionalism, and other skills that are required for long-run sustainability. The organizations that did not consider brand as an asset due to their poor marketing capability in the practices of culture, people, and processes their results may be differently related to brand equity and shareholder value. Thus, Brand Equity can be a tool or key to enhancing the shareholder value of a company, because investors have an important role in the company's investments. Based on the above mentioned, the hypothesis will be written.

H3: Brand Equity have a positive relationship with Shareholder Value of companies.

\section{Mediating effect of Brand Equity between Corporate Social Responsibility \& Shareholder Value.}

Researchers connected brand equity with distinct variables to study its significance. In this research, brand equity is examined as a mediating variable between CSR and Shareholder value. With the lapse of time, consumers demand, and desires are growing due to advancement and improvements in the information technologies and communication. Industry sector has realized the strength of the brand and implements it as a competitive tool to keep up sustainable advantage called brand equity.

The array of a causal relationship through which independent variable shows its effect on the dependent variable through the effect of the overriding third variable is mediation [136]. The latter aids the ability to evaluate the total effect (direct effect plus indirect effect). However, in order to know the mediation process, adopt [137] four steps provide guidance that defends brand equity as a mediator in relation to this study.

1. There will be a significant association among the independent and dependent variable. Based on the analysis made earlier, CSR and Shareholder value have a significant relationship. [102, 104, 105, 107, 138].

2. There will be a significant association between the independent variable and the mediator variable. Base on the analysis made earlier, CSR and Brand Equity have a significant relationship. [120-123, 125].

3. There will be a significant association between the dependent variable and the mediator. The literature shows that a significant association between existing between Brand Equity and Shareholder Value.[27, 131-133].

4. There must be the involvement of Brand Equity (i.e mediator and indirect association become significant) that makes the direct association between CSR and Shareholder Value turns out to be zero. Then there occurs a full mediation. If the direct connection is significantly minimized, then there is a partial mediation, but if the direct link is still significant no mediation takes place.

Further, in the scenario of assumption to [136] and from the literature discussed above, it is stated that brand equity can be a mediator in the association between CSR and Shareholder value because it has a significant relationship with both independent (CSR) and dependent (Shareholder value) variables. Therefore, the following is the hypothesis.

H4: Brand Equity may mediate the relationship between corporate social responsibility and Shareholder value of companies.

\section{CONCLUSION AND RECOMMENDATIONS FOR FUTURE RESEARCH.}

It is absolutely inevitable to be apparent about the importance for implementing 
these theories in business or in any other research that, they are not adoptable simultaneously, but a combination of them, will assist to have diverse studies accomplish establish on strong theoretical underpinnings that are necessary to affirm the findings of research efforts. The concerns linked with corporate social responsibility can update the understanding of operators in the different aspects of capital ventures that include brand equity and shareholder value. Therefore, this review has proposed the theoretical relationship between CSR and shareholder value on one side and on the other side the association among CSR and Brand Equity as well the mediating factor of brand equity between CSR and shareholder value. For future research, this model can be applied to other less developing and developed countries of the world and maybe a comparison of cross-culture countries.

\section{REFERENCES.}

[1] Shocker, A.D. and S.P. Sethi, An approach to incorporating societal preferences in developing corporate action strategies. California management review, 1973. 15(4): p. 97-105.

[2] Roberts, R.W., Determinants of corporate social responsibility disclosure: An application of stakeholder theory. Accounting, organizations and society, 1992. 17(6): p. 595-612.

[3] Lee, I.B., Corporate law, profit maximization, and the responsible shareholder. Stan. JL Bus. \& Fin., 2004. 10: p. 31.

[4] Anderson, R.C., S.A. Mansi, and D.M. Reeb, Founding family ownership and the agency cost of debt. Journal of Financial economics, 2003. 68(2): p. 263-285.

[5] Solomon, J.F. and A. Solomon, Private social, ethical and environmental disclosure. Accounting, Auditing \& Accountability Journal, 2006. 19(4): p. 564-591.

[6] Quarterly, M., Valuing corporate social responsibility: McKinsey global survey results. Survey February, 2009. 2009: p. 1-9.

[7] Luo, X. and C.B. Bhattacharya, The debate over doing good: Corporate social performance, strategic marketing levers, and firm-idiosyncratic risk. Journal of Marketing, 2009. 73(6): p. 198-213.

[8] Arora, P. and R. Dharwadkar, Corporate governance and corporate discrepancy and organization slack. Corporate governance: an international review, 2011. 19(2): p. 136-152.

[9] Albus, H. and H. Ro, Corporate social responsibility: The effect of green practices in a service recovery. Journal of Hospitality \& Tourism Research, 2017. 41(1): p. 41-65.

[10] Kim, M. and Y. Kim, Corporate social responsibility and shareholder value of restaurant firms. International Journal of Hospitality Management, 2014. 40: p. 120-129.

[11] Reich, A.Z., Y.H. Xu, and K.W. McCleary, The influence of social responsibility image relative to product and service quality on brand loyalty: an exploratory study of quick-service restaurants. Hospitality Review, 2010. 28(1): p. 2.

[12] Du, S., C.B. Bhattacharya, and S. Sen, Maximizing business returns to corporate social responsibility (CSR): The role of CSR communication. International journal of management reviews, 2010. 12(1): p. 8-19.

[13] Bhattacharya, C.B. and S. Sen, Doing better at doing good: When, why, and how consumers respond to corporate social initiatives. California management review, 2004. 47(1): p. 9-24.

[14] Melo, T. and A. Garrido-Morgado, Corporate reputation: A combination of social responsibility and industry. Corporate social responsibility and environmental management, 2012. 19(1): p. 11-31.

[15] Maignan, I. and O. Ferrell, Antecedents and benefits of corporate citizenship: An investigation of French businesses. Journal of Business Research, 2001. 51(1): p. 37-51.

[16] Melo, T. and J.I. Galan, Effects of corporate social responsibility on brand value. Journal of Brand Management, 2011. 18(6): p. 423-437.

[17] Godfrey, P.C., The relationship between corporate philanthropy and shareholder wealth: A risk management perspective. Academy of management review, 2005. 30(4): p. 777-798. social responsibility $(C S R)$ : The moderating roles of attainment

[18] Hoeffler, S. and K.L. Keller, Building brand equity through corporate societal marketing. Journal of Public Policy \& Marketing, 2002. 21(1): p. 78-89.

[19] Till, B.D. and L.I. Nowak, Toward effective use of cause-related marketing alliances. Journal of Product \& Brand Management, 2000. 9(7): p. 472-484.

[20] Barone, M.J., A.T. Norman, and A.D. Miyazaki, Consumer response to retailer use of cause-related marketing: Is more fit better? Journal of Retailing, 2007. 83(4): p. 437-445.

[21] Lai, C.-S., et al., The effects of corporate social responsibility on brand performance: The mediating effect of industrial brand equity and corporate reputation. Journal of business ethics, 2010. 95(3): p. 457-469.

[22] Cable, D.M. and D.B. Turban, The value of organizational reputation in the recruitment context: A brand-equity perspective. Journal of Applied Social Psychology, 2003. 33(11): p. 2244-2266.

[23] Wang, R.-T., Modeling corporate social performance and job pursuit intention: Mediating mechanisms of corporate reputation and job advancement prospects. Journal of Business Ethics, 2013. 117(3): p 569-582.

[24] Smith, J., The companies with the best CSR reputations. Retrieved May, 2012. 11: p. 2017.

[25] Hsu, K.-T., The advertising effects of corporate social responsibility on corporate reputation and brand equity: Evidence from the life insurance industry in Taiwan. Journal of business ethics, 2012. 109(2): p. 189-201.

[26] Cuneo, A., P. Lopez, and M. Jesus Yagüe, Measuring private labels brand equity: a consumer perspective. European Journal of Marketing, 2012. 46(7/8): p. 952-964.

[27] Madden, T.J., F. Fehle, and S. Fournier, Brands matter: An empirical demonstration of the creation of shareholder value through branding. Journal of the Academy of Marketing Science, 2006. 34(2): p. 224-235.

[28] Fehle, F., et al., Brand value and asset pricing. Quarterly Journal of Finance and Accounting, 2008: p. 3-26.

[29] Chaudhuri, A. and M.B. Holbrook, The chain of effects from brand trust and brand affect to brand performance: the role of brand loyalty. Journal of marketing, 2001. 65(2): p. 81-93.

[30] Berthon, P., et al., Viewing brands in multiple dimensions. MIT Sloan Management Review, 2007. 48(2): p. 37.

[31] Haigh, D., An introduction to brand equity - How to understand and appreciate brand value and the economic impact of brand investment. Interactive Marketing, 2003. 5(1): p. 21-32.

[32] Berg, J.D., J.M. Matthews, and C.M. O'Hare, Measuring brand health to improve top-line growth. MIT Sloan Management Review, 2007. 49(1): p. 61

[33] Young, S.D., et al., EVA and value-based management. 2000 McGraw-Hill Professional Publishing.

[34] Luo, X., When marketing strategy first meets wall street: Marketing spendings and firms' initial public offerings. Journal of Marketing, 2008. 72(5): p. 98-109.

[35] Rust, R.T., et al., Measuring marketing productivity: Current knowledge and future directions. Journal of marketing, 2004. 68(4): p. 76-89.

[36] Keller, K.L., Building, Measuring, and Managing Brand Equity. 2013.

[37] Brodie, R.J., M.S. Glynn, and J. Van Durme, Towards a theory of marketplace equity: integrating branding and relationship thinking with financial thinking. Marketing Theory, 2002. 2(1): p. 5-28.

[38] Day, G. and L. Fahey, Valuing market strategies. Journal of Marketing, 1988. 52(3): p. 45-57.

[39] Srivastava, R.K., T.A. Shervani, and L. Fahey, Market-based assets and shareholder value: A framework for analysis. Journal of marketing, 1998. 62(1): p. 2-18.

[40] Gruca, T.S. and L.L. Rego, Customer satisfaction, cash flow, and shareholder value. Journal of marketing, 2005. 69(3): p. 115-130.

[41] Currim, I.S., J. Lim, and Y. Zhang, Effect of analysts' earnings pressure on marketing spending and stock market performance. Journal of the Academy of Marketing Science, 2018. 46(3): p. 431-452.

[42] Fine, M.B., K. Gleason, and M. Mullen, Marketing spending and aftermarket performance of IPO firms. Marketing Intelligence \& Planning, 2017. 35(4): p. 560-576.

[43] Fornell, C., F.V. Morgeson III, and G.T.M. Hult, Stock returns on customer satisfaction do beat the market: gauging the effect of a marketing intangible. Journal of Marketing, 2016. 80(5): p. 92-107.

[44] Lev, B., Sharpening the intangibles edge. Harvard business review, 2004. 6: p. 109-116.

[45] Katsikeas, C.S., et al., Assessing performance outcomes in marketing. Journal of Marketing, 2016. 80(2): p. 1-20. 
[46] Kotler, P. and W. Pfoertsch, Ingredient branding: making the invisible visible. 2010: Springer Science \& Business Media.

[47] Davcik, N.S., R. Vinhas da Silva, and J.F. Hair, Towards a unified theory of brand equity: conceptualizations, taxonomy and avenues for future research. Journal of Product \& Brand Management, 2015. 24(1): p. 3-17.

[48] Aaker, D., Aaker on branding: 20 principles that drive success. 2014: Morgan James Publishing.

[49] Lieven, T. and C. Hildebrand, The impact of brand gender on brand equity: Findings from a large-scale cross-cultural study in ten countries. International Marketing Review, 2016. 33(2): p. 178-195.

[50] Aaker, D.A. and M.B. Equity, Capitalizing on the Value of a Brand Name. New York, 1991. 28: p. 35-37.

[51] Kotler, P. and W. Pfoertsch, B2B brand management. 2006: Springer Science \& Business Media.

[52] Kapferer, J.-N., The new strategic brand management: Advanced insights and strategic thinking. 2012: Kogan page publishers.

[53] Datta, H., K.L. Ailawadi, and H.J. van Heerde, How well does consumer-based brand equity align with sales-based brand equity and marketing-mix response? Journal of Marketing, 2017. 81(3): p. 1-20.

[54] Frieder, L. and A. Subrahmanyam, Brand perceptions and the market for common stock. Journal of financial and Quantitative Analysis, 2005. 40(1): p. 57-85.

[55] Freeman, R., 1984, Strategic Management: A stakeholder approach. Boston: Pitman. 1984.

[56] Freeman, R.E., A.C. Wicks, and B. Parmar, Stakeholder theory and "the corporate objective revisited". Organization science, 2004. 15(3): p. 364-369.

[57] Schaefer, B.P., Shareholders and social responsibility. Journal of Business Ethics, 2008. 81(2): p. 297-312.

[58] Lee, M.D.P., A review of the theories of corporate social responsibility: Its evolutionary path and the road ahead. International journal of management reviews, 2008. 10(1): p. 53-73.

[59] Alchian, A.A. and H. Demsetz, Production, information costs, and economic organization. The American economic review, 1972. 62(5): p. 777-795.

[60] Jensen, M.C. and W.H. Meckling, Theory of the firm: Managerial behavior, agency costs and ownership structure. Journal of financial economics, 1976. 3(4): p. 305-360.

[61] Hill, C.W. and T.M. Jones, Stakeholder-agency theory. Journal of management studies, 1992. 29(2): p. 131-154.

[62] Cornell, B. and A.C. Shapiro, Corporate stakeholders and corporate finance. Financial management, 1987: p. 5-14.

[63] McWilliams, A. and D. Siegel, Corporate social responsibility and financial performance: correlation or misspecification? Strategic management journal, 2000. 21(5): p. 603-609.

[64] Alexander, G.J. and R.A. Buchholz, Corporate social responsibility and stock market performance. Academy of Management journal, 1978. 21(3): p. 479-486.

[65] Barnea, A. and A. Rubin, Corporate social responsibility as a conflict between shareholders. Journal of business ethics, 2010. 97(1): p. 71-86.

[66] Cheers, Z., The corporate social responsibility debate. 2011.

[67] McWilliams, A. and D.S. Siegel, Creating and capturing value: Strategic corporate social responsibility, resource-based theory, and sustainable competitive advantage. Journal of Management, 2011. 37(5): p. 1480-1495.

[68] Wernerfelt, B., A resource-based view of the firm. Strategic management journal, 1984. 5(2): p. 171-180.

[69] Jones, K. and J.L. Bartlett, The strategic value of corporate social responsibility: a relationship management framework for public relations practice. PRism, 2009. 6(1).

[70] Srivastava, R.K., L. Fahey, and H.K. Christensen, The resource-based view and marketing: The role of market-based assets in gaining competitive advantage. Journal of management, 2001. 27(6): p. 777-802.

[71] Barney, J., Firm resources and sustained competitive advantage. Journal of management, 1991. 17(1): p. 99-120.

[72] Grant, R.M., The resource-based theory of competitive advantage: implications for strategy formulation. California management review, 1991. 33(3): p. 114-135.

[73] Ness, M.R., Corporate social responsibility. British food journal, 1992. 94(7): p. 38-44.

[74] Friedman, M., A Friedman doctrine: The social responsibility of business is to increase its profits. The New York Times Magazine, 1970. 13(1970): p. 32-33.

[75] Carroll, A.B., The pyramid of corporate social responsibility: Toward the moral management of organizational stakeholders. Business horizons, 1991. 34(4): p. 39-48.
[76] Friedman, M., Capitalism and freedom: With the assistance of Rose D. Friedman. 1962: University of Chicago Press.

[77] Carroll, A.B., A three-dimensional conceptual model of corporate performance. Academy of management review, 1979. 4(4): p. 497-505.

[78] Alchian, A.A., Private property and the relative cost of tenure. The public stake in Union power, 1959. 350.

[79] Kyriazis, D. and C. Anastassis, The validity of the economic value added approach: an empirical application. European Financial Management, 2007. 13(1): p. 71-100.

[80] Helfert, E.A. and E.A. Helfert, Financial analysis: tools and techniques: a guide for managers. 2001: McGraw-Hill New York.

[81] Kamakura, W.A. and G.J. Russell, Measuring brand value with scanner data. International journal of Research in Marketing, 1993. 10(1): p. 9-22

[82] Stahl, F., et al., The impact of brand equity on customer acquisition retention, and profit margin. Journal of marketing, 2012. 76(4): p. 44-63.

[83] Keller, K.L., Conceptualizing, measuring, and managing customer-based brand equity. Journal of marketing, 1993. 57(1): p $1-22$.

[84] Mahajan, V., V.R. Rao, and R.K. Srivastava, An approach to assess the importance of brand equity in acquisition decisions. Journal of Product Innovation Management: AN INTERNATIONAL PUBLICATION OF THE PRODUCT DEVELOPMENT \& MANAGEMENT ASSOCIATION, 1994. 11(3): p. 221-235.

[85] Park, C.S. and V. Srinivasan, A survey-based method for measuring and understanding brand equity and its extendibility. Journal of marketing research, 1994. 31(2): p. 271-288

[86] Ailawadi, K.L., D.R. Lehmann, and S.A. Neslin, Revenue premium as an outcome measure of brand equity. Journal of marketing, 2003. 67(4): p. 1-17.

[87] Kay, M.J., Strong brands and corporate brands. European journal of marketing, 2006. 40(7/8): p. 742-760.

[88] Douglas, S.P., C.S. Craig, and E.J. Nijssen, Executive insights. Integrating branding strategy across markets: Building international brand architecture. Journal of International Marketing, 2001. 9(2): p 97-114.

[89] Steenkamp, J.-B.E., R. Batra, and D.L. Alden, How perceived brand globalness creates brand value. Journal of International Business Studies, 2003. 34(1): p. 53-65.

[90] Farquhar, P., Managing Brand Equity'Marketing Research. 1989, September.

[91] Simon, C.J. and M.W. Sullivan, The measurement and determinants of brand equity: a financial approach. Marketing science, 1993. 12(1): p. 28-52.

[92] Mahajan, V., V. Rao, and R. Srivastava, Model for Assessing Impact of Brand Strength on Investment Decisions. Marketing Science Institute Report, 1991(91-110): p. 14-15.

[93] Ourusoff, A., et al., \{1992)," What's in a Name? What the World's Top Brands Are Worth,". Financial World: p. 32-49.

[94] Keller, K.L. and D.R. Lehmann, Brands and branding: Research findings and future priorities. Marketing science, 2006. 25(6): p. 740-759.

[95] Crawford, C.M., New products management. 2008: Tata McGraw-Hill Education.

[96] Sharma, P., N.S. Davcik, and K.G. Pillai, Product innovation as a mediator in the impact of $R \& D$ expenditure and brand equity on marketing performance. Journal of Business Research, 2016. 69(12): $\mathrm{p}$ 5662-5669.

[97] Kerin, R.A. and R. Sethuraman, Exploring the brand value-shareholder value nexus for consumer goods companies. Journal of the Academy of Marketing Science, 1998. 26(4): p. 260.

[98] Starks, L.T., EFA keynote speech:"Corporate governance and corporate social responsibility: What do investors care about? What should investors care about?". Financial Review, 2009. 44(4): p. 461-468.

[99] Freeman, R.E., The politics of stakeholder theory: Some future directions. Business ethics quarterly, 1994: p. 409-421.

[100]Statman, M. and D. Glushkov, The wages of social responsibility Financial Analysts Journal, 2009. 65(4): p. 33-46.

[101]Filbeck, G., R. Gorman, and X. Zhao, The "best corporate citizens". are they good for their shareholders? Financial Review, 2009. 44(2): p. 239-262.

[102]Jo, H. and M.A. Harjoto, Corporate governance and firm value: The impact of corporate social responsibility. Journal of

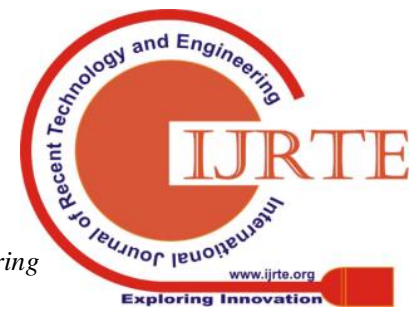


business ethics, 2011. 103(3): p. 351-383.

[103] Jo, H. and M.A. Harjoto, The causal effect of corporate governance on corporate social responsibility. Journal of business ethics, 2012. 106(1): p. 53-72.

[104]Adeneye, Y.B. and M. Ahmed, Corporate social responsibility and company performance. Journal of Business Studies Quarterly, 2015. 7(1): p. 151.

[105]Rashid, A., Does corporate social responsibility reporting enhance shareholders' value? A simultaneous equation approach. Journal of Financial Reporting and Accounting, 2018. 16(1): p. 158-178.

[106]Bagh, T., et al., The Corporate Social Responsibility and Firms Financial Performance: Evidence from Financial Sector of Pakistan. International Journal of Economics and Financial Issues, 2017. 7(2): p 301-308.

[107]Iyanar, Y. and R. Prasad. Impact of CSR Activities on Shareholders' Wealth in Indian Companies. in 2018 International Conference on Advances in Computing, Communications and Informatics (ICACCI). 2018. IEEE.

[108]Kotler, P., et al., Marketing.--Pearson Education Australia. 2006.

[109]Morgan, R.M. and S.D. Hunt, The commitment-trust theory of relationship marketing. Journal of marketing, 1994. 58(3): p. 20-38.

[110] Yoo, B. and N. Donthu, Developing and validating a multidimensional consumer-based brand equity scale. Journal of business research, 2001. 52(1): p. 1-14.

[111]de Mortanges, C.P. and A. Van Riel, Brand equity and shareholder value. European management journal, 2003. 21(4): p. 521-527.

[112]Baalbaki, S. and F. Guzmán, A consumer-perceived consumer-based brand equity scale. Journal of Brand Management, 2016. 23(3): p. 229-251.

[113]Chatzipanagiotou, K., C. Veloutsou, and G. Christodoulides, Decoding the complexity of the consumer-based brand equity process. Journal of Business Research, 2016. 69(11): p. 5479-5486.

[114]Grönroos, C. and P. Voima, Critical service logic: making sense of value creation and co-creation. Journal of the academy of marketing science, 2013. 41(2): p. 133-150.

[115]Ind, N., O. Iglesias, and M. Schultz, Building brands together: Emergence and outcomes of co-creation. California Management Review, 2013. 55(3): p. 5-26.

[116]Kennedy, E. and F. Guzmán, Co-creation of brand identities: consumer and industry influence and motivations. Journal of Consumer Marketing, 2016. 33(5): p. 313-323.

[117]Iglesias, O., N. Ind, and M. Alfaro, The organic view of the brand: A brand value co-creation model, in Advances in corporate branding 2017, Springer. p. 148-174.

[118]Gyrd-Jones, R.I. and N. Kornum, Managing the co-created brand: Value and cultural complementarity in online and offline multi-stakeholder ecosystems. Journal of Business Research, 2013. 66(9): p. 1484-1493.

[119] Vallaster, C. and S. von Wallpach, An online discursive inquiry into the social dynamics of multi-stakeholder brand meaning co-creation. Journal of Business Research, 2013. 66(9): p. 1505-1515.

[120]Hur, W.-M., H. Kim, and J. Woo, How CSR leads to corporate brand equity: Mediating mechanisms of corporate brand credibility and reputation. Journal of Business Ethics, 2014. 125(1): p. 75-86.

[121]Nguyen, C.N. and R. Oyotode, The moderating effect of marketing capabilities on the relationship between changes in CSR perceptions and changes in brand equity. International Management Review, 2015. 11(1): p. 17.

[122]Esmaeilpour, M. and S. Barjoei, The impact of corporate social responsibility and image on brand equity. Global Business and Management Research, 2016. 8(3): p. 55.

[123] Singh, A. and P. Verma, How CSR affects brand equity of Indian firms? Global Business Review, 2017. 18(3 suppl): p. S52-S69.

[124]Kang, J.-W. and Y. Namkung, The effect of corporate social responsibility on brand equity and the moderating role of ethical consumerism: The case of Starbucks. Journal of Hospitality \& Tourism Research, 2018. 42(7): p. 1130-1151.

[125] Yang, J. and K. Basile, The impact of corporate social responsibility on brand equity. Marketing Intelligence \& Planning, 2019. 37(1): p. 2-17

[126]AAKER, D., Building Strong Brands, First Edt. 1996, The Free Press A Division Of Simon \& Schuster Inc., New York. S.

[127]Doyle, P., Building value-based branding strategies. Journal of Strategic Marketing, 2001. 9(4): p. 255-268.

[128]Lane, V. and R. Jacobson, Stock market reactions to brand extension announcements: The effects of brand attitude and familiarity. Journal of Marketing, 1995. 59(1): p. 63-77.

[129]de Mortanges, C.P. and A.T. Rad, Marketing strategy and market value:: An event-study analysis. European Management Journal, 1998. 16(3): p. $365-371$

[130]Nayyar, P.R., Stock market reactions to customer service changes. Strategic Management Journal, 1995. 16(1): p. 39-53.

[131]Bharadwaj, S.G., K.R. Tuli, and A. Bonfrer, The impact of brand quality on shareholder wealth. Journal of Marketing, 2011. 75(5): p. 88-104.

[132]Voss, K. and M. Mohan, Good times, bad times: the stock market performance of firms that own high value brands. European Journal of Marketing, 2016. 50(5/6): p. 670-694.

[133]Yildiz, Y. and S. Metin Camgoz, Brand Equity and Firm Risk: An Empirical Investigation in an Emerging Market. Emerging Markets Finance and Trade, 2019. 55(1): p. 218-235.

[134]de Oliveira, M.O.R., A.A. Stefanan, and M.L. Lobler, Brand equity, risk and return in Latin America. Journal of Product \& Brand Management, 2018. 27(5): p. 557-572.

[135]Erdem, T. and J. Swait, Brand equity as a signaling phenomenon. Journal of consumer Psychology, 1998. 7(2): p. 131-157.

[136]Hayes, A.F., Introduction to mediation, moderation, and conditional process analysis: Methodology in the Social Sciences. Kindle Edition, 2013. 193.

[137]Baron, R.M. and D.A. Kenny, The moderator-mediator variable distinction in social psychological research: Conceptual, strategic, and statistical considerations. Journal of personality and social psychology, 1986. 51(6): p. 1173.

[138]Masoud, N. and A. Halaseh, Corporate social responsibility and company performance: An empirical analysis of Jordanian companies listed on Amman Stock Exchange. British Journal of Education, Society and Behavioural Science 19 (1): 1, 2017. 26.

\section{AUTHORS PROFILE}

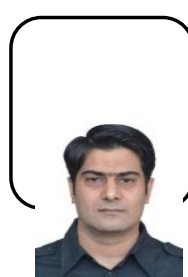

Innovation,

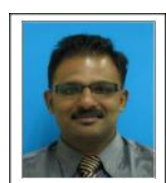

Asim Ali Chaudhry, PhD Scholar in Azman Hashim International Business School at Universiti Teknologi Malaysia, Johor Bahru, Skudai Malaysia

$1^{\text {st }}$ publication in Scopus journal.

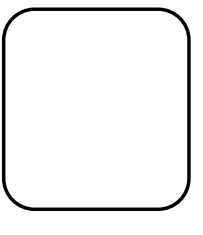
Lecturer, Deputy Dean (Research, Development \& Alumni), Internationa Business School, Universiti Teknologi Malaysia.

$\mathrm{Ph}$. D (Finance), Deakin University 41 publications. 